\title{
Control of Phytoparasitic Nematodes Attacking Sorghum (Sorghum bicolor (L.) Moench) in Puerto Rico ${ }^{1}$
}

\author{
Alejandro Ayala and Domingo Bee ${ }^{2}$
}

\begin{abstract}
Under laboratory conditions, Fensulfothion (20 lb/acre), D-D (40 gal/ acre), and Vorlex (40 gal/acre) increased dry weights of sorghum roots over those of the controls, two other nematicides, and two fungicides. Under field conditions methyl bromide $\left(1 \mathrm{lb} / 100 \mathrm{ft}^{2}\right)$ was highly effective in one experiment but not in a second one. Preplant soil treatments with methyl bromide, Fensulfothion ( $30 \mathrm{lb} /$ acre and D-D (40 gal/acre) increased plant top dry weights 132,106 , and $66 \%$, respectively, over the control plants. Vorlex (40 gal/acre), D-D (40 gal/acre) and Fensulfothion (20 lb/acre) significantly increased plant top dry weight over nontreated plants and the Oxamyl and Phenamiphos treatments. Of three different dosages evaluated, $20 \mathrm{lb} /$ acre of Fensulfothion and $60 \mathrm{gal}$ of D-D/acre significantly increased sorghum plant tops dry weight by $44 \%$ over the controls. Both under field and greenhouse conditions, soil fungicides and insecticides failed to produce significant increases. Nematode population levels and $\mathrm{pH}$ were lower in plants showing symptoms of abnormal growth with purple leaves and reddish rootlets than in healthy-looking plants free of the symptoms; $\mathrm{Al}$ concentration was higher in soil around stunted plants.
\end{abstract}

\section{INTRODUCTION}

Sorghum (Sorghum bicolor (L.) Moench) is cultivated in Puerto Rico mostly for experimental purposes, although its production for animal feed is steadily increasing. Field studies have demonstrated that both local and introduced varieties are highly susceptible to pests and diseases, among which nematodes are an important limiting factor. The nematode species most commonly encountered in association with sorghum roots are Pratylenchus zeae, various species of Helicotylenchus, and Tylenchorhynchus crassycaudatus. Other genera, such as Aphelenchus, Aphelenchoides, Tylenchus, Pseudhalenchus, Trophurus, Neotylenchus, Longidorus, Meloidogyne, and Rotylenchulus are sporadically isolated from soil and root samples.

The world sorghum production for 1967-68 was estimated to be $\$ 795,555,000$, whereas the losses due to nematode damage amounted to $\$ 47,733,300$ (8).

In spite of the world-wide importance of this crop, the literature available on the control of sorghum nematodes is extremely limited.

${ }^{1}$ Manuscript submitted to Editorial Board December 22, 1976.

${ }^{2}$ Nematologist, and Graduate Student, respectively, Department of Entomology, Agricultural Experiment Station, University of Puerto Rico, Mayagüez Campus, Mayagüez, P.R. This research was sponsored by USAID under research contract ta-c1087. 
Johnson and Burton (6) found that $11.2 \mathrm{~kg}$ of Temik and Phenamiphos per hectare increased growth and yields of millet and Sudan grass hybrids in plots infected with phytoparasitic nematodes, including Pratylenchus brachyurus and P. zeae.

Scientific personnel of the Mayagüez Institute of Tropical Agriculture observed an abnormal condition of young sorghum plants at the experimental grounds at Isabela. Two or three weeks after germination most plants turned purplish, wilted, and died in a few days, a symptom typical of dieback. The roots turned deep red and the cortex was loosened. Nematodes of the species $P$. zeae were invariably associated with the symptoms.

TABLE 1. - Average plant height, fresh and dry weights of tops and roots from greenhouse experiment for the chemical control of a sorghum disease

\begin{tabular}{lrrrrc}
\hline \multirow{2}{*}{ Treatments } & & \multicolumn{4}{c}{ Weight } \\
\cline { 3 - 6 } & Height & \multicolumn{3}{c}{ Top } & \multicolumn{2}{c}{ Root } \\
\cline { 3 - 6 } & & Fresh & Dry & Fresh & Dry \\
\cline { 3 - 6 } & & $G$ & $G$ & $G$ & $G$ \\
Fensulfothion 20 lb/acre & $112.4 \mathrm{a}^{1}$ & $36.65 \mathrm{a}$ & $6.1 \mathrm{~b}$ & $46.28 \mathrm{a}$ & $6.58 \mathrm{a}$ \\
D-D 40 gal/acre & $125.8 \mathrm{a}$ & $50.25 \mathrm{a}$ & $9.5 \mathrm{ab}$ & $42.68 \mathrm{a}$ & $4.78 \mathrm{a}$ \\
Vorlex 40 gal /acre & $117.8 \mathrm{a}$ & $36.97 \mathrm{a}$ & $6.7 \mathrm{ab}$ & $43.96 \mathrm{a}$ & $4.78 \mathrm{a}$ \\
Oxamyl 30 lb/acre & $108.2 \mathrm{a}$ & $35.25 \mathrm{a}$ & $6.7 \mathrm{ab}$ & $41.02 \mathrm{a}$ & $4.52 \mathrm{ab}$ \\
Fumazone 1.5 gal/acre & $116.6 \mathrm{a}$ & $44.85 \mathrm{a}$ & $7.3 \mathrm{ab}$ & $33.42 \mathrm{a}$ & $3.62 \mathrm{ab}$ \\
Benomyl 0.5 lb/100 gal water & $114.2 \mathrm{a}$ & $40.85 \mathrm{a}$ & $10.9 \mathrm{ab}$ & $31.46 \mathrm{a}$ & $3.44 \mathrm{~b}$ \\
Control & $117.2 \mathrm{a}$ & $46.45 \mathrm{a}$ & $10.3 \mathrm{ab}$ & $30.64 \mathrm{a}$ & $2.52 \mathrm{~b}$ \\
Terraclor 4 lb/100 gal water & $37.8 \mathrm{~b}$ & $7.56 \mathrm{~b}$ & - & $7.72 \mathrm{~b}$ & $.52 \mathrm{~b}$ \\
\hline
\end{tabular}

${ }^{1}$ Means in the same column followed by one or more letters in common do not differ significantly at the .05 level by Duncan's new Multiple Range Test.

It was therefore deemed important to evaluate some nematicidal treatments both under greenhouse and field conditions. It was also decided to evaluate different dosages of various nematicides in an effort to determine the most effective treatment against the condition.

\section{MATERIALS AND METHODS}

To evaluate different nematicides and various dosages of each, five experiments, one in the greenhouse and four in the field, were performed. For the greenhouse test, clay pots were filled with infected Coto clay (Oxisol) from Isabela. Table 1 indicates the chemicals and dosages used. A completely randomized block design, with treatments replicated five times, was used.

Nematode populations in soil samples $\left(100 \mathrm{~cm}^{3}\right.$ each) were assessed by sieve and funnel methods (12) before applying the nematicides and at harvest. Nematicides were pipetted into punched holes in each pot and seeds of the hybrid variety Lindsay $101 \mathrm{~F}$ were set 8 days later. 
Plants were harvested after 11 weeks and the following parameters considered: final nematode populations in soil and roots, plant height, and dry and fresh weights of stems, leaves, and roots.

The four field experiments were conducted in a Coto clay at the experimental farm at Isabela. Table 2 shows the treatments used in the first test. Plots were $15 \mathrm{ft} \times 15 \mathrm{ft}$ with rows $3 \mathrm{ft}$ apart and plants 3 in apart. Only the center rows were harvested. D-D ${ }^{3}$ was applied with a hand injector, Fensulfothion was sprayed and plowed under. Dexon, Terraclor and Aldrin were sprayed. Methyl bromide was applied under a tarp which was removed after the fifth day. Seeds of the hybrid

TABLE 2. - Means of fresh and dry weights of field plant tops (variety Lindsay 101F) treated with different chemicals to control a sorghum disease

\begin{tabular}{|c|c|c|c|}
\hline \multirow{2}{*}{ Treatments } & \multicolumn{2}{|c|}{ Weight (cwt/acre) } & \multirow{2}{*}{$\begin{array}{l}\text { Increased } \\
\text { dry weight }\end{array}$} \\
\hline & Fresh & Dry & \\
\hline & & & $\%$ \\
\hline MC2 $1 \mathrm{lb} . / 100 \mathrm{ft}^{1}$ & $90.34 \mathrm{a}^{1}$ & $22.28 \mathrm{a}$ & 132 \\
\hline D-D $40 \mathrm{gal} / \mathrm{acre}$ & $67.08 \mathrm{bc}$ & $16.00 \mathrm{bc}$ & 66 \\
\hline Fensulfothion $30 \mathrm{lb} /$ acre & $80.27 \mathrm{ab}$ & $19.78 \mathrm{ab}$ & 106 \\
\hline Dexon 0.5 lb/100 gal. water & $60.06 \mathrm{bcd}$ & $12.95 \mathrm{bcd}$ & 34 \\
\hline Aldrin 2 lb/acre & $61.03 \mathrm{bcd}$ & $14.06 \mathrm{bed}$ & 46 \\
\hline Terraclor $1 \mathrm{lb} / 100$ gal water & $43.54 \mathrm{~cd}$ & $9.76 \mathrm{~cd}$ & 1 \\
\hline Control & $42.44 \mathrm{~d}$ & $9.59 \mathrm{~d}$ & - \\
\hline
\end{tabular}

${ }^{1}$ Means in the same column followed by one or more letters in common do not differ significantly at the .05 level by Duncan's new Multiple Range Test.

Lindsay $101 \mathrm{~F}$ were sown 8 days after treatments and plants were harvested 16 weeks afterward.

The nematode counts were performed before treatment, 1 month afterward, and at harvest. Only fresh and dry weights of stems and leaves were recorded for comparison.

In the second experiment, the same nematicides were evaluated; different dosages of the fungicides Terraclor and Dexon were used. The insecticide Chlordane, substituted for Aldrin, and the fungicide Benomyl were used as an additional treatment. Variety T.E. Haygrazer was planted in plots $10 \mathrm{ft} \times 20 \mathrm{ft}$ with only three rows. Table 3 includes the treatments used. Soil samples for the analysis of nematode populations, $\mathrm{pH}$, and $\mathrm{Al}, \mathrm{Fe}, \mathrm{Zn}, \mathrm{Mg}$, and $\mathrm{P}$ concentration were taken from large and small plants from each plot for comparison.

${ }^{3}$ Trade names are used in this publication solely for the purpose of providing specific information. Mention of a trade name does not constitute a guarantee or warranty of equipment or materials by the Agricultural Experiment Station of the University of Puerto Rico or an endorsement over other equipment or materials not mentioned. 
In the last two field experiments, the methods used were similar to those used in the first two. The fertilizer was added at time of planting and plants were watered by sprinkler when needed. Lannate was sprayed regularly for the control of foliar insects. Terraclor (2 lb ai/100 gal water) and Dieldrin (1 lb/100 gal water) were sprayed to eliminate the fungi and soil insect factors. Table 4 gives the nematicides and dosages evaluated in experiment number four. In experiment number five, three dosages of D-D and Fensulfothion were compared with a control as shown in table. 5 .

\section{RESULTS}

\section{GREENHOUSE TEST}

Table 1 shows the results from the greenhouse test. The plants from all treatments including the controls were significantly better in

TABLE 3. - Yields of fresh and dry weights of sorghum (variety T. E. Haygrazer) tops from field experiment for the evaluation of various pesticides

\begin{tabular}{lcc}
\hline \multicolumn{1}{c}{ Treatments } & Fresh weight & Dry weight \\
\hline & Cwt/acre & Cwt/acre \\
D-D -40 gal/acre & $58.41^{1}$ & $31.01 \mathrm{a}$ \\
Chlordane-4 lb/acre & 44.59 & $16.38 \mathrm{ab}$ \\
Methyl bromide - 1 lb/100 gal water & 35.59 & $14.00 \mathrm{ab}$ \\
Terraclor -4 lb/100 gal water & 31.33 & $11.33 \mathrm{ab}$ \\
Fensulfothion-20 lb/acre & 37.76 & $10.69 \mathrm{ab}$ \\
Benomyl -0.5 lb/100 gal water & 20.57 & $10.36 \mathrm{ab}$ \\
Dexon-1.5 lb/gal water & 22.58 & $7.39 \mathrm{ab}$ \\
Control & 11.25 & $4.50 \mathrm{~b}$ \\
\hline
\end{tabular}

1 Means in the same column followed by one or more letters in common do not differ significantly at the .05 level by Duncan's new Multiple Range Test.

growth, and fresh and dry weights of tops and roots than those growing in soil treated with Terraclor. The plants from the latter treatment showed severe symptoms of phytotoxity. Plants treated with Fensulfothion, D-D, and Vorlex developed healthier root systems than the controls, as evidenced by root dry weights.

Nematode populations (fig. 1) were lower at the end of the experiment in all nematicide treatments except those receiving D-D. The number of $P$. zeae recovered from the roots was significantly higher in the controls and the Terraclor-treated plant roots.

\section{FIELD EXPERIMENTS}

Table 2 shows the results from the first field experiment to evaluate the effect of several chemicals including fumigants of a wide spectrum, nematicides, insecticides, and fungicides. The higher top fresh weights 
TABLE 4. - Soil pH, phytoparasitic nematode populations, P. zeae populations in $1 \mathrm{~g}$ of roots, and soil analysis from soil around small and tall sorghum plants

\begin{tabular}{|c|c|c|c|c|c|c|c|c|c|c|c|c|c|c|c|c|}
\hline \multirow[b]{2}{*}{ Treatments } & \multirow[b]{2}{*}{$\mathrm{pH}$} & \multicolumn{2}{|c|}{ Small plants } & \multirow[b]{2}{*}{$\mathrm{Fe}$} & \multirow[b]{2}{*}{$\mathrm{Mn}$} & \multirow[b]{2}{*}{$\mathrm{Al}$} & \multirow[b]{2}{*}{$\mathrm{Zn}$} & \multirow[b]{2}{*}{$\mathrm{P}$} & \multirow[b]{2}{*}{$\mathrm{pH}$} & \multicolumn{2}{|c|}{ Tall plants } & \multirow[b]{2}{*}{$\mathrm{Fe}$} & \multirow[b]{2}{*}{$\mathrm{Mn}$} & \multirow[b]{2}{*}{$\mathrm{Al}$} & \multirow[b]{2}{*}{$\mathrm{Zn}$} & \multirow[b]{2}{*}{$\mathrm{P}$} \\
\hline & & $\begin{array}{l}\text { Nematodes } \\
\text { in } 250 \mathrm{~cm}^{3} \\
\text { of soil }\end{array}$ & $\begin{array}{l}\text { P. zeae } \\
\text { in } 1 \mathrm{~g} \\
\text { roots }\end{array}$ & & & & & & & $\begin{array}{l}\text { Nematodes } \\
\text { in } 250 \mathrm{~cm}^{3} \\
\text { of soil }\end{array}$ & $\begin{array}{l}P . \text { zeae } \\
\text { in } 1 \mathrm{~g} \\
\text { roots }\end{array}$ & & & & & \\
\hline & \multicolumn{11}{|c|}{$\mu g / g$} & \multicolumn{5}{|c|}{$\mu g / g$} \\
\hline $\mathrm{MC} 2$ & 4.50 & 80 & 8 & 6 & 109 & 635 & 3 & 17 & 4.70 & 80 & 0 & 7 & 224 & 445 & 3 & 10 \\
\hline D-D & 4.45 & 300 & 60 & 7 & 112 & 660 & 4 & 18 & 4.65 & 1920 & 64 & 6 & 144 & 395 & 3 & 12 \\
\hline Fensulfothion & 4.45 & 480 & 0 & 10 & 103 & 575 & 10 & 17 & 5.00 & 720 & 80 & 5 & 101 & 370 & 1 & 18 \\
\hline Dexon & 4.50 & 80 & 0 & 6 & 100 & 475 & 3 & 11 & 4.55 & 1040 & 264 & 7 & 143 & 470 & 3 & 13 \\
\hline Chlordane & 4.45 & 800 & 440 & 8 & 104 & 635 & 3 & 15 & 4.70 & 1060 & 272 & 6 & 135 & 470 & 2 & 12 \\
\hline Terraclor & 4.30 & 0 & 320 & 4 & 104 & 635 & 2 & 16 & 4.55 & 1600 & 544 & 6 & 140 & 450 & 3 & 9 \\
\hline Benomlyl & 4.40 & 1760 & 120 & 8 & 129 & 504 & 2 & 17 & 4.65 & 2160 & 168 & 5 & 106 & 429 & 3 & 13 \\
\hline Control & 4.45 & 640 & 460 & 7 & 113 & 475 & 3 & 12 & 4.60 & 960 & 152 & 5 & 92 & 505 & 2 & 13 \\
\hline
\end{tabular}


were obtained after fumigating the soil with $1 \mathrm{lb}$ of methyl bromide/100 $\mathrm{ft}^{2}$, followed in effectiveness by Fensulfothion (30 lb ai/acre) and D-D (40 gal/acre). The fumigation with methyl bromide increased the top fresh weights significantly over those of all other treatments except the Fensulfothion-treated plots, which in turn exceeded significantly those of Terraclor and the controls. The methyl bromide-treated plots increased the dry weights significantly over those of all other treatments, except those that received Fensulfothion, which in turn was superior to all treatments except D-D and Aldrin. The best three treatments increased the dry weights 132,106 , and $66 \%$, respectively, over the controls. Both fungicides (Dexon and Terraclor) and the insecticide Aldrin failed to increase top and root weights significantly. Both

TABLE 5.-Mean fresh and dry weights of plant tops in experiment for the evaluation of different nematicides for the control of sorghum nematodes (variety T. E. Haygrazer)

\begin{tabular}{|c|c|c|c|}
\hline \multirow{2}{*}{ Treatments } & \multicolumn{2}{|c|}{ Weight } & \multirow{2}{*}{$\begin{array}{l}\text { Increase } \\
\text { dry weight }\end{array}$} \\
\hline & Fresh & Dry & \\
\hline & \multicolumn{2}{|c|}{ Cwt/acre } & \\
\hline Vorlex $30 \mathrm{gal} /$ acre & $130.93 \mathrm{a}^{1}$ & $43.04 \mathrm{a}$ & 54.0 \\
\hline D-D $40 \mathrm{gal} /$ acre & $113.65 \mathrm{ab}$ & $38.03 \mathrm{ab}$ & 36.0 \\
\hline Fensulfothion $20 \mathrm{lb} /$ acre & $101.63 \mathrm{abc}$ & $34.87 \mathrm{ab}$ & 25.0 \\
\hline Oxamyl 15 lb/acre & $82.94 \mathrm{bc}$ & $28.15 \mathrm{~b}$ & .8 \\
\hline Control & $105.67 \mathrm{bc}$ & $27.90 \mathrm{~b}$ & - \\
\hline Phenamiphos $20 \mathrm{lb} /$ acre & $73.78 c$ & $25.60 \mathrm{~b}$ & 8.2 \\
\hline
\end{tabular}

${ }^{1}$ Means in the same column followed by the same letters do not differ significantly at the .05 level by Duncan's new Multiple Range Test.

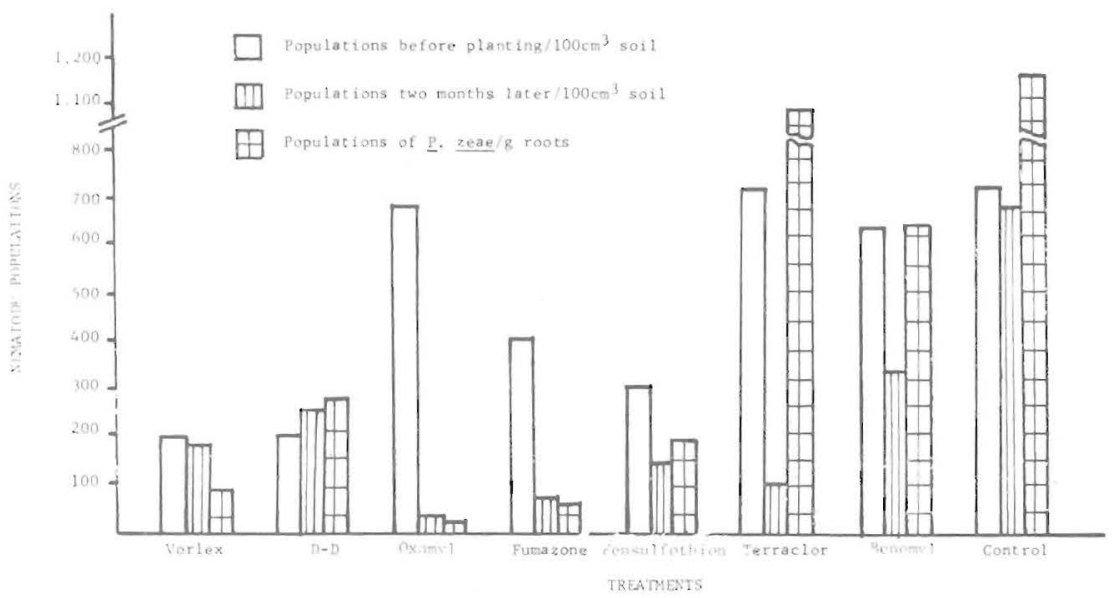

FIG. 1. - Populations of phytoparasitic nematodes before treatment; 2 months afterward; and populations of $P$. zeae in $1 \mathrm{~g}$ roots, from greenhouse test. 

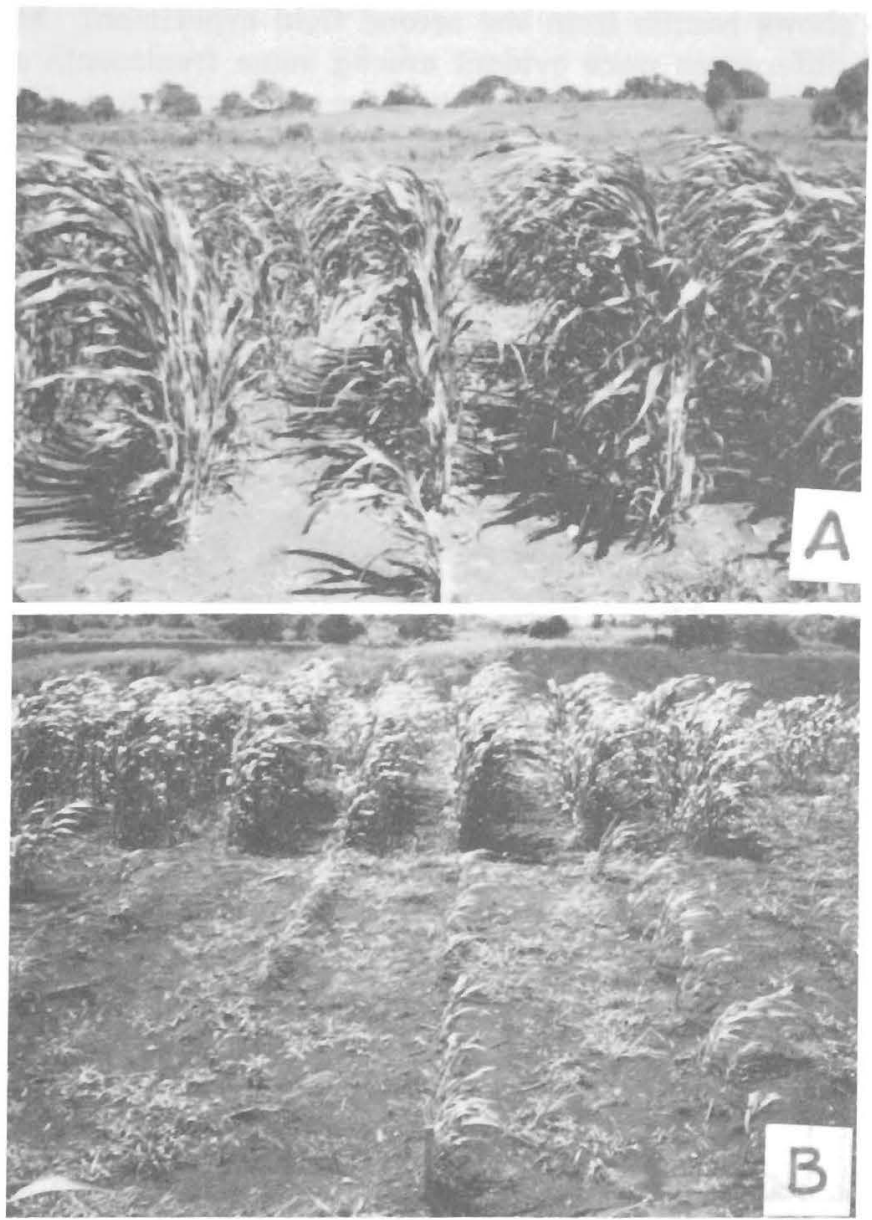

FIG. 2.-A. Plot treated with $1 \mathrm{lb}$ methyl bromide/100 ft²; B. Foreground, control plot; background, plot treated with $1 \mathrm{lb}$ methyl bromide/100 $\mathrm{ft}^{2}$.

germination and growth were uniform in plots treated with chemicals with nematicidal effects, whereas germination was sporadic and growth slow and uneven in soil treated with fungicides, insecticides and in the nontreated checks. (fig. 2).

Nematode populations remained low throughout the experiment in plots treated with methyl bromide and Fensulfothion. In D-D-treated soil, populations decreased after treatment but were high at harvest. With Dexon, Terraclor, and Aldrin, nematode populations at harvest were much higher than before treatment; also they increased during the experiment in the control plots (fig. 3). 
Table 3 shows results from the second field experiment. Although numerical differences were evident among some treatments and the controls, differences in fresh weights were not significant. However, the dry weights of tops from plants grown in soil treated with 40 gals of D-D/acre were significantly higher than those of the controls. The remaining treatments failed to produce significant differences (fig. 4).

Methyl bromide caused the best nematode kill; D-D and Phenamiphos followed. The Dexon-treated plots had the highest nematode counts; in Benomyl- and Chlordane-treated soil, counts remained low.

Growth and development in most treatments were rather irregular. Soil around smaller and larger plants was chemically analyzed separately (table 4). Soil $\mathrm{pH}$ varied from 4.30 to 4.50 around the small

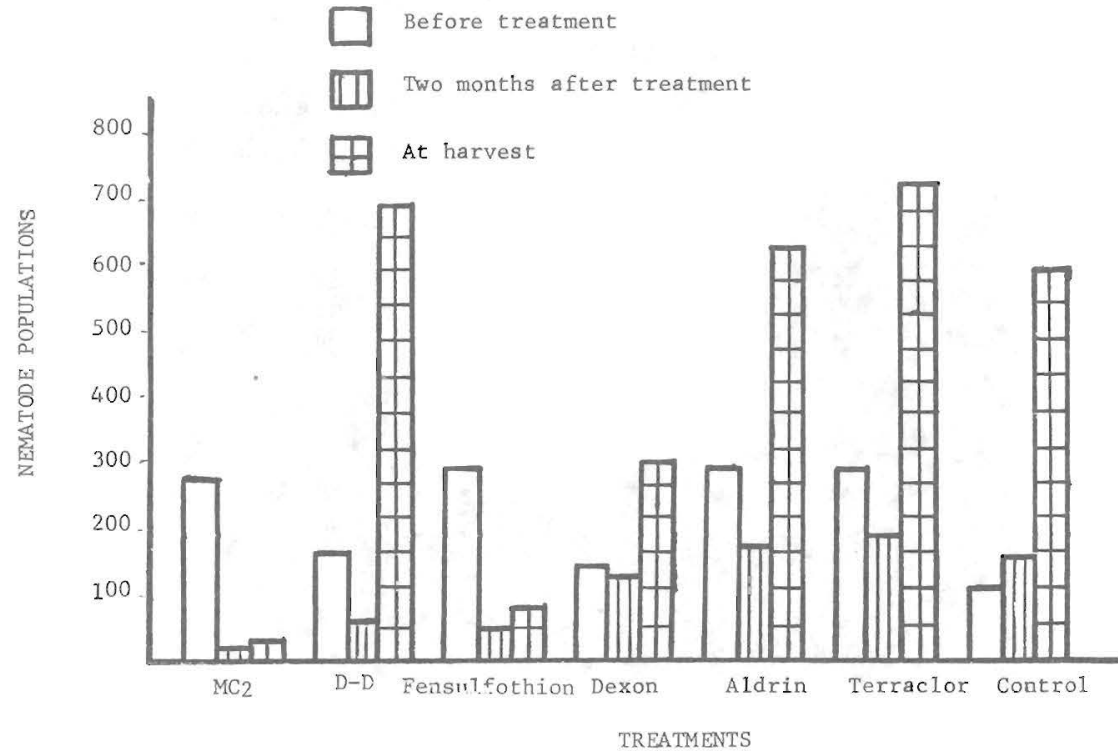

FIG. 3. - Nematode population/ $250 \mathrm{~cm}^{3}$ of soil from field experiment for the evaluation of different pesticides for the control of an abnormal condition of sorghum.

plants and from 4.55 to 5.00 around taller plants. The $\mathrm{Al}$ content was much higher in the soil around small plants than around taller ones. Leaf analysis did not show appreciable differences. $\mathrm{P}$ and minor elements, such as $\mathrm{Fe}, \mathrm{Mn}$, and $\mathrm{Zn}$, did not vary much in relation to plant growth and vigor. Nematode populations varied, being more numerous around healthy plants.

Table 5 shows the results from the third field experiment to evaluate five nematicides. Vorlex (30 gal/acre) increased the fresh top weights over Oxamyl (15 lb/acre), Phenamiphos (20 lb/acre), and the controls. 
D-D (40 gal/acre) was significantly superior to the controls; the remaining treatments were not effective. Vorlex increased the top dry weights $54 \%$ over the controls and was significantly better also over Oxamyl and Phenamiphos. D-D, Oxamyl, and Phenamiphos failed to increase top dry weights. Sorghum growth and appearance in Vorlex-treated soil was much better than in the controls (fig. 5).

Nematode reproduction was curtailed during early plant growth with the nematicides evaluated, but populations increased by the end of the experiment with all treatments but Phenomiphos (fig. 6).

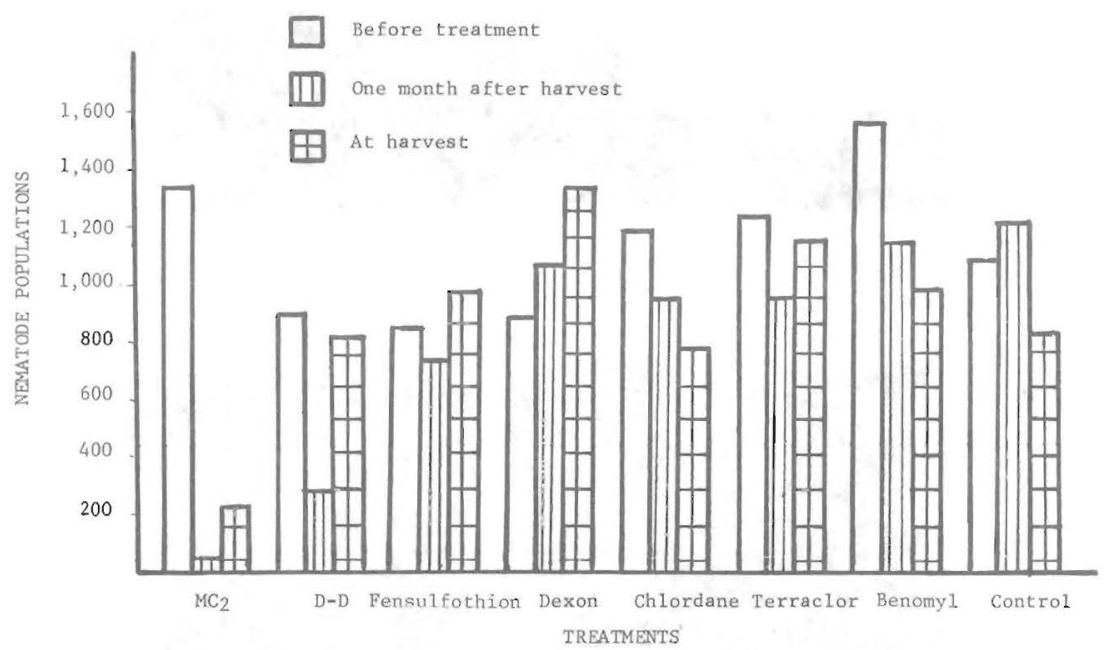

FIG. 4. - Populations of phytoparasitic nematodes $/ 250 \mathrm{~cm}^{3}$ of soil from experiment for the control of sorghum nematodes under field conditions.

Table 6 includes the results of the last experiment with three different dosages of D-D and Fensulfothion. Significant increases in top dry weights were obtained only after applying 60 gal/acre of D-D (46.99 cwt/acre) or $20 \mathrm{lb} /$ acre of Fensulfothion ( $46.95 \mathrm{cwt} / \mathrm{acre})$. These values were $44 \%$ higher than those of the controls. Although the fresh weights were numerically higher and plants were much healthier (fig. 7) after applying the said dosages, differences were not significant.

All chemicals except $20 \mathrm{lb}$ of. Fensulfothion (fig. 8) reduced nematode populations in the soil.

\section{DISCUSSION AND CONCLUSIONS}

The fumigation of soil highly infested with phytoparasitic nematodes with the nematicides D-D, Vorlex, or Fensulfothion under greenhouse conditions significantly increased root dry weights over the controls. 

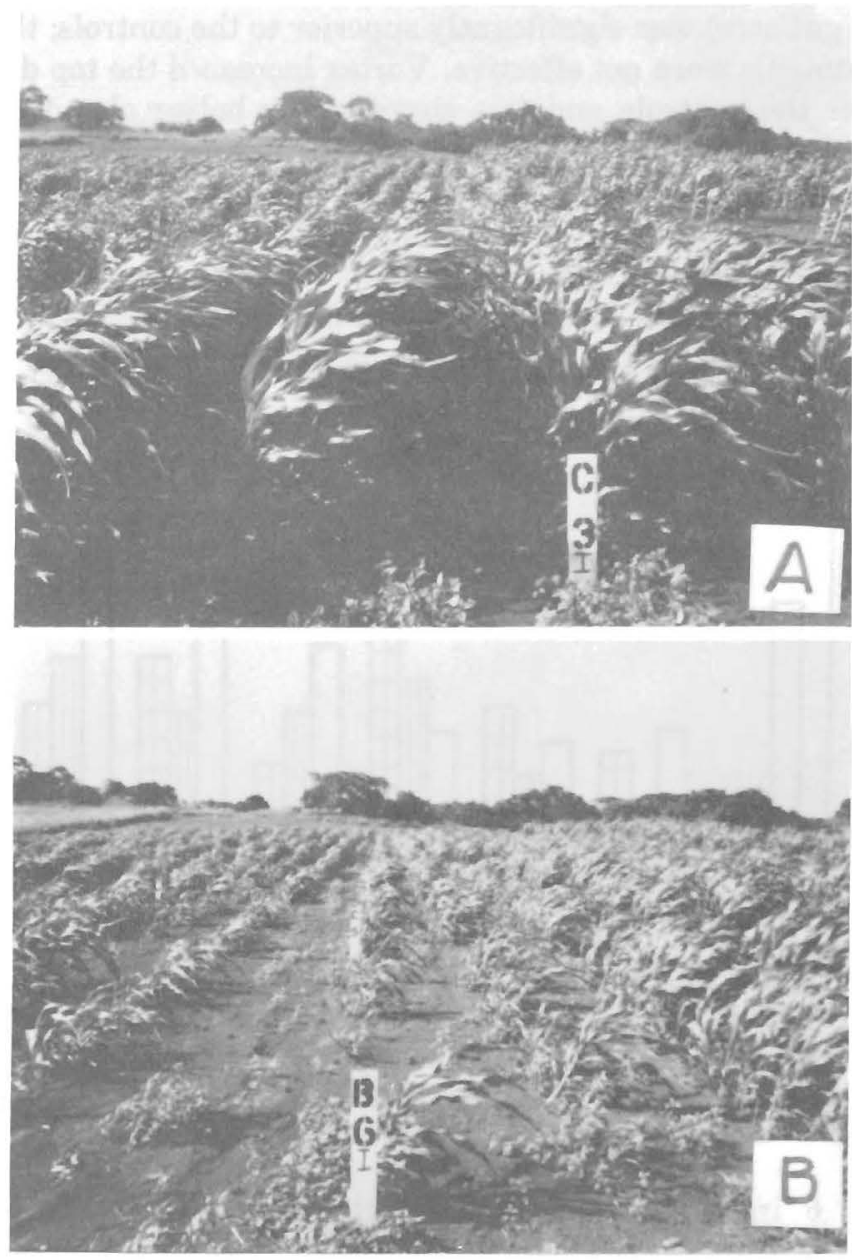

FiG. 5.-A. Sorghum plants from plot treated with $30 \mathrm{gal}$ Vorlex/acre, Aldrin, and Terraclor; B. Sorghum plants grown in soil treated with Aldrin and Terraclor, but no nematicide.

However, the typical symptoms prevalent under field conditions were not expressed in the controls. This may have been because the high temperatures prevailing during the experiment reduced the reproductive potential or the pathogenic capabilities of such nematode species as $P$. zeae. Besides, the soil was always at optimum humidity which may interfere with symptom expression; under field conditions, plants are exposed to stress due to the lack of enough moisture. Microorganisms such as nematodes, fungi, and bacteria, and the concentration of toxic elements such as $\mathrm{Al}$ tend to do more damage under conditions of stress. 
Some conclusions may be warranted by the results obtained from field experiments. Nematodes seem to be involved in a disease observed at the Isabela farm of the Mayagüez Institute of Tropical Agriculture because in most cases significant results were obtained when nematicides were employed. In the first two experiments a soil insecticide and three soil fungicides were used with very slight results. Methyl bromide and Vorlex, chemicals of a wide spectrum against insects, fungi, nematodes, and weeds were very effective. But in most cases, their beneficial effects were not significantly better than those produced by a specific nematicide such as D-D.

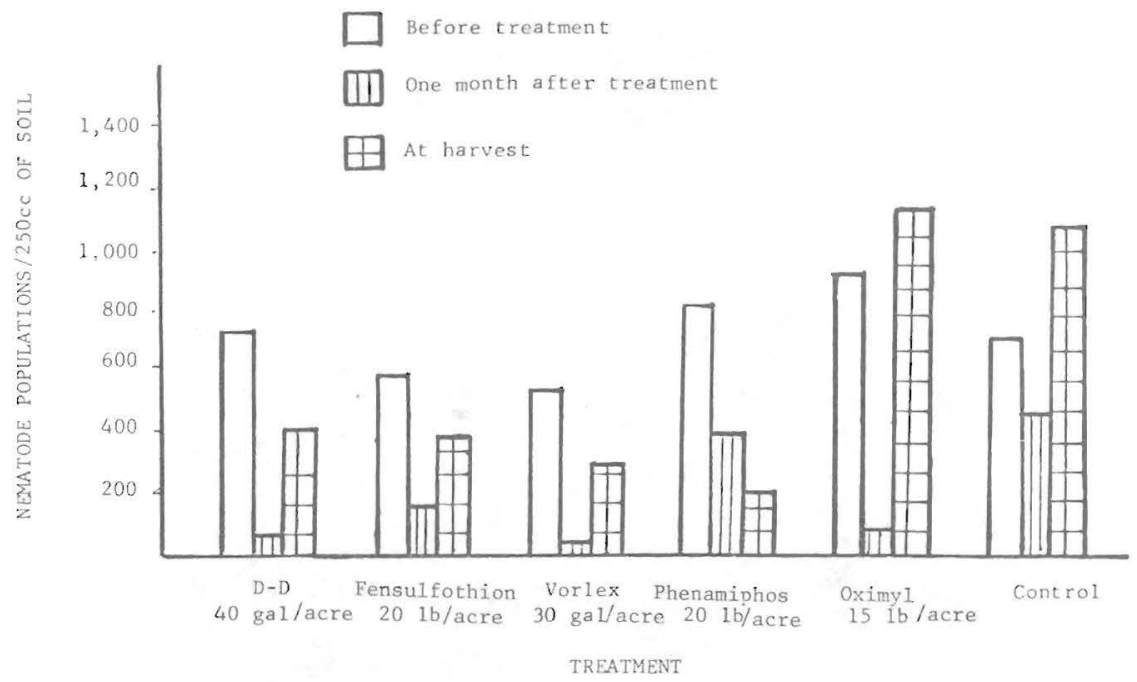

FIG. 6. - Phytoparasitic nematode populations $/ 250 \mathrm{~cm}^{3}$ of soil from experiment for the evaluation of nematicides in sorghum.

TABLE 6. - Means of fresh and dry weights of sorghum (variety T. E. Haygrazer) plants from field experiment to evaluate three dosages of the nematicides Dasanit and D-D

\begin{tabular}{lccc}
\hline \multicolumn{1}{c}{ Treatment } & Fresh weight & Dry weight & $\begin{array}{c}\text { Increase } \\
\text { dry weight }\end{array}$ \\
\hline & Cwt/acre & Cwt/acre & $\%$ \\
D-D -60 gal/acre & $141.26 \mathrm{a}^{1}$ & $46.97 \mathrm{a}$ & 44 \\
Fensulfothion -20 lb/acre & $140.17 \mathrm{a}$ & $46.95 \mathrm{a}$ & 44 \\
Fensulfothion-40 lb/acre & $121.39 \mathrm{a}$ & $43.06 \mathrm{ab}$ & 32 \\
D-D - 15 gal/acre & $111.73 \mathrm{a}$ & $39.05 \mathrm{ab}$ & 20 \\
D-D-30 gal/acre & $102.49 \mathrm{a}$ & $33.48 \mathrm{ab}$ & 3 \\
Fensulfothion-10 lb/acre & $96.76 \mathrm{a}$ & $33.10 \mathrm{ab}$ & 1 \\
Control & $111.46 \mathrm{a}$ & $32.48 \mathrm{~b}$ & - \\
\hline
\end{tabular}

${ }^{1}$ Means in the same column followed by one or more letters in common do not differ significantly at the .05 level by Duncan's Multiple Range Test. 

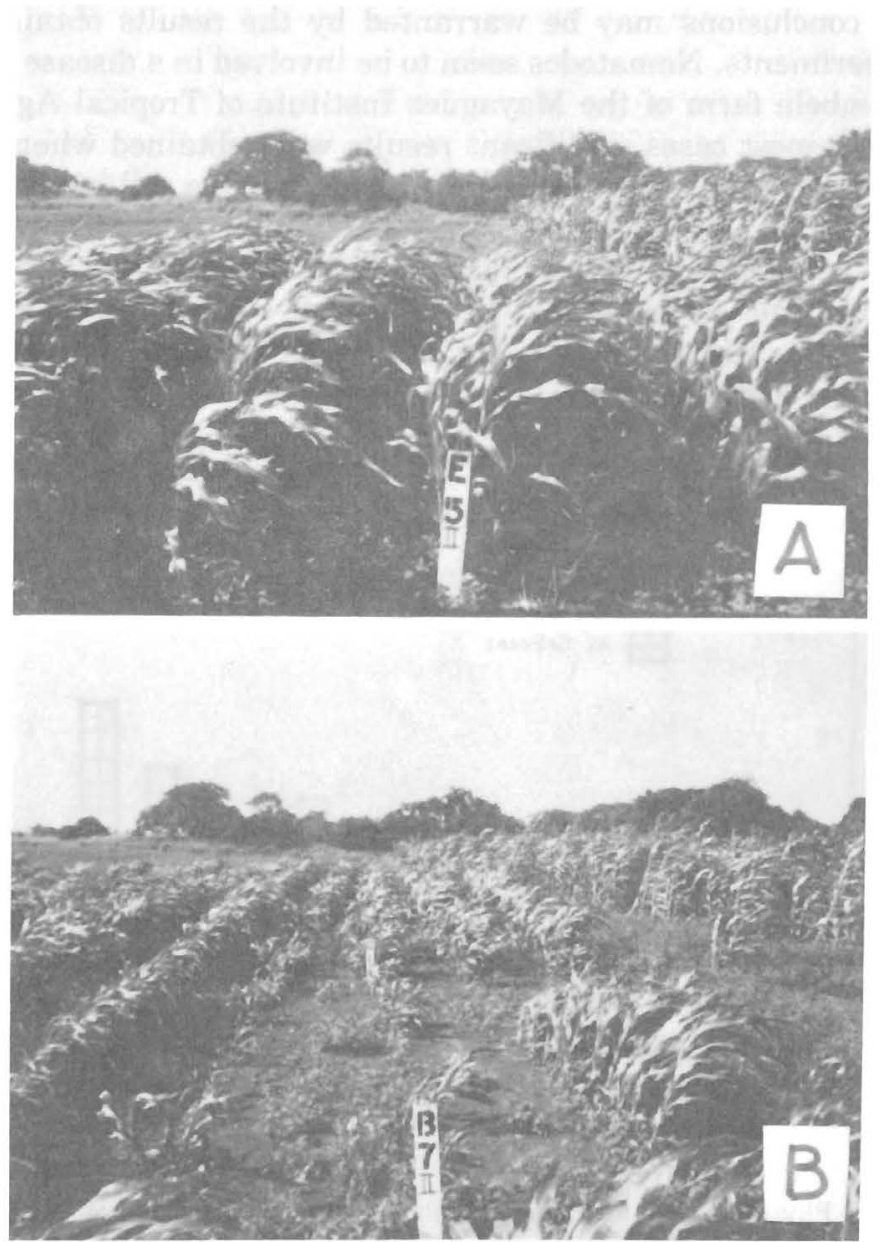

FIG. 7. - A. Sorghum plants from plot treated with $20 \mathrm{lb}$ ai of Fensulfothion /acre; B. Sorghum plants from nontreated plot.

The most effective dosage of D-D seems to be between 40 and $60 \mathrm{gal} /$ acre, which is evidenced in two of the field experiments. The optimum dosage for Fensulfothion is around $30 \mathrm{lb} / \mathrm{acre}$. The use of other nematicides such as Phenamiphos and Oxamyl as pre-plant treatments should be explored further, especially with higher dosages, and combined with foliar sprays.

The possibility of interactions between nematodes $P$. zeae and Helicotylenchus spp.) with pathogenic soil fungi of the genera Pythium, Curvularia, Fusarium, Macrophomina, and Rhizoctonia still remains; these were often found in association with sorghum roots (unpublished data of the authors). 
Soil pH may affect the reproductive potential, survival, and pathogenic capabilities of $P$. zeae and other nematode species. This was apparent in the second field experiment where nematode populations were lower in roots from small plants growing in acid soils, whereas populations were higher in soils with $\mathrm{pH}$ values closer to the neutral point. Willis (9) reported that the reproductive potential of Pratylenchus penetrans in alfalfa is greatly reduced at $\mathrm{pH} 4.4$; the optimum $\mathrm{pH}$ values for its development were between 5.2 and 6.4. Low soil $\mathrm{pH}$

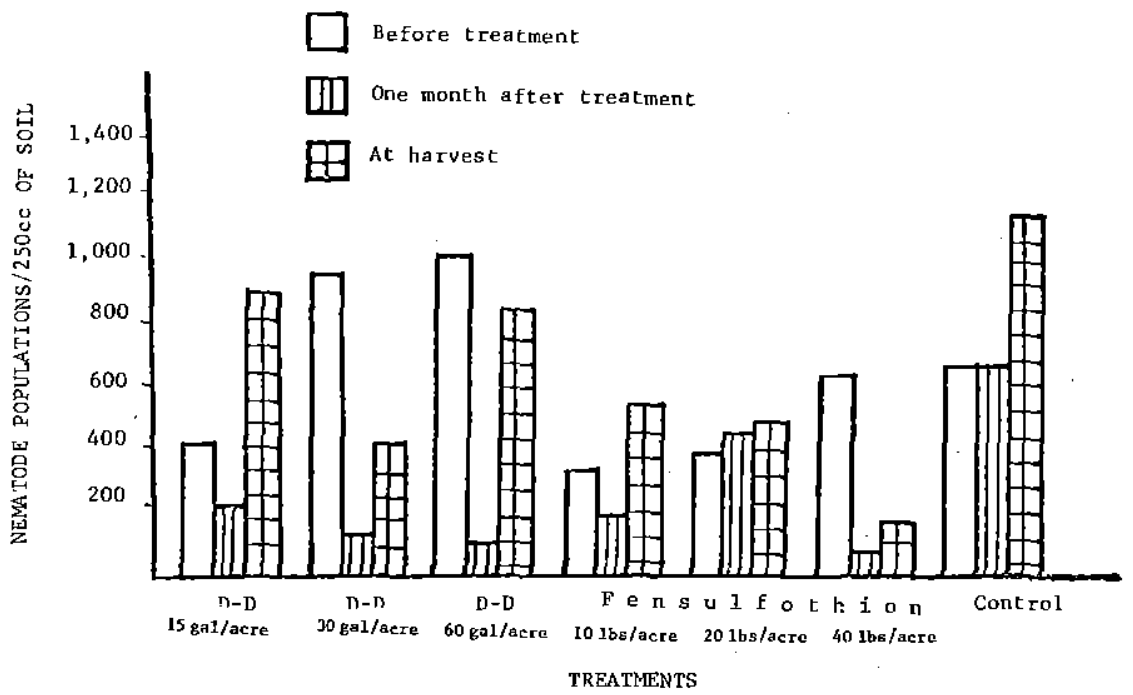

FIG. 8. - Phytoparasitic nematode populations $/ 250 \mathrm{~cm}^{3}$ of soil from experiment for the evaluation of three dosages of two different nematicides for the control of sorghum nematodes under field conditions.

leading to Al toxicity and possibly $\mathrm{P}$ deficiency also may, either alone or interacting with phytopathogenic nematodes, affect the plant.

The Al concentration was extremely high where plants did not grow normally and lower in spots where plants grew well. Al toxicity alone or interacting with nematode and fungi damage, low $\mathrm{pH}$, and toxic residues of the previous crop could be the cause of the poor growth. The reported observations agree with those of Hoffer and Carr (4) and Hoffer and Trost (5) who reported that $\mathrm{Al}$ is toxic to corn and renders it more susceptible to a root rot caused by Fusarium moniliforme. Brenes and Pearson (1), and Ligon and Pierre (7) found that sorghum roots are more sensitive than corn roots to high $\mathrm{Al}$ concentration.

Previous crop residues may also have affected sorghum growth and interfered with the results. This may have been the case because the second experiment where plant growth was rather uneven was set just 
1 month after eliminating a previous sorghum planting. Two years elapsed between the previous sorghum crop and setting the last two experiments, plants of which had uniform and normal growth. Guenzi et al. (3) reported on the phytotoxic compounds present in extracts of wheat, corn, oats, and sorghum, which inhibited the growth by 2,15 , 55 , and $81 \%$ respectively. They also observed that the toxicity of sorghum extracts on wheat increased up to 16 weeks after harvesting.

\section{RESUMEN}

Con aplicaciones de los nematicidas Fensulfothion granulado, D-D y Vorlex (líquido) a razón de $20 \mathrm{lb}, 40$ y 40 galones por acre, respectivamente, a plantas de sorgo sembradas en invernadero, se logró sobrepasar en peso seco de las raíces, los de las plantas testigo y los de las que recibieron aplicaciones insecticidas y fungicidas. En las sembradas a la intemperie, la aplicación de bromuro metílico, a razón de $1 \mathrm{lb} . / 100 \mathrm{p}^{2}$ fue muy eficaz en uno de dos experimentos. En todos los experimentos las plantas se sembraron en un suelo Coto arcilloso (Oxisol).

Cuando el bromuro metílico, Fensulfothion (30 lb./acre) y D-D (40 lb./acre) se aplicaron antes de la siembra, el peso seco de las plantas aumentó 132, 106 y 66\%, respectivamente sobre los de las plantas testigo. Vorlex y D-D (ambos a razón de 40 galones por acre) también los aumentaron sobre el de éstas y sobre los de las plantas sembradas en suelo tratado con Oxamyl y Phenamiphos. De tres dosis evaluadas, las de $20 \mathrm{lb}$. de Fensulfothion y $60 \mathrm{lb}$. de D-D, aumentaron el peso seco un $40 \%$ sobre el de las plantas testigo. Tanto en el invernadero como en el campo, las aplicaciones insecticidas y fungicidas fueron ineficaces.

El pH del suelo era más bajo y la población de nematodos fitoparasíticos menos densa en el suelo de la rizosfera en plantas de poco crecimiento en comparación con las de crecimiento normal. En las primeras, la concentración de aluminio en el suelo era mucho más elevada.

\section{LITERATURE CITED}

1. Brenes, E., and Pearson, R. W., 1973. Root responses of three gramineae species to soil acidity in an Oxisol and an Ultisol, Soil Sci. 116: 295-302.

2. Christie, J. R., and Perry, V. G., 1951. Removing nematodes from soil, Proc. Helminth. Soc. Wash. 18: 106-8.

3. Guenzi, W. D., McCalla, T. M., and Norstadt, F. A., 1967. Presence and persistence of phytotoxic substances in wheat, oat, corn, and sorghum residues, Agron. J. 59: $163-5$.

4. Hoffer, G. N. and Carr, P. H., 1923. Accumulation of aluminum and iron compounds in corn plants and its probable relation to root rot, J. Agric. Res. 23: 801-23.

ミ. Hoffer, G. N., and Trost, J. F., 1923. The accumulation of iron and aluminum compounds in corn plants and its probable relation to corn roots rot, II, J. Amer. Soc. Agron., 15: 323-31.

6. Johnson, A. W., and Burton, G. W., 1973. Comparison of millet and sorghumsudan grass hybrids grown in untreated soil and soil treated with two nematocides, J. Nematol. 5: 148-9.

7. Ligon, W. S., and Pierre, W. H., 1932. Soluble aluminum studies. II. Minimum concentrations of aluminum found to be toxic to corn, sorghum, and barley in culture solutions, Soil Sci. 34: 307-21.

8. Society of Nematologists, Committee of Crop Losses, 1971. Estimated crop losses due to plant-parasitic nematodes in the United States, J. Nematol. Supplement Special Publication No. 1, 7pp.

9. Willis, C. B., 1972. Effects of soil $\mathrm{pH}$ on reproduction of Pratylenchus penetrans and forage yield of alfalfa, J. Nematol. 4(4): 291-5. 